\title{
Formulation of a Certification Agency for Buildings without Land Rights Based on the Principle of Horizontal Separation (Comparison to Japan)
}

\author{
Lilawati Ginting ${ }^{1}$, Tan Kamello², Muhammad Yamin ${ }^{3}$, OK. Saidin ${ }^{4}$ \\ \{lilawati.ginting@gmail.com $\left.{ }^{1}\right\}$ \\ Universitas Sumatera Utara, Indonesia ${ }^{1,2,3,4}$
}

\begin{abstract}
This research discusses the proof of building ownership based on the principle of horizontal separation. Is it possible for the Government of Indonesia to create a special agency for building certification without land rights? The Indonesian agrarian law adheres to the principle of horizontal separation, where a party can construct a building on land owned by another. To be able to protect their rights, the owner of the building requires proof of ownership that is separate from the proof of land ownership on which the building stands. As building is classified as immovable property namely object adhered to the soil, a written proof (certificate) is required as proof of ownership. This is normative descriptive research. The results show that the Indonesian government can establish a special agency for building certification without land rights, such as the National Land Agency (NLA) to ensure that buildings without land rights can possess legal certainty which enables them to be used as collateral.
\end{abstract}

Keywords: Certification, Building, Horizontal Separation Principle

\section{Introduction}

Customary law adheres to the principle of horizontal separation that is legally concrete, clear, and cash. This principle enables the legal separation of buildings or plants with the land that it is erected on. This is in accordance with the customary law that does not recognize the existence of objects that are auxiliary (hulpzaak), supplementary (bijzaak), embedded in the ground (aardvast), or planted in the ground (carrotvast). Meanwhile, the Basic Agrarian Law approaches the principle of horizontal separation in a more abstract and consensual way involving matters relating to formality [1].

With the implementation of this principle in the Indonesian land law, it is possible to separate the rights to a plot of land and the objects erected above [2].

The principle of horizontal separation is also adopted by Japan. According to the law of real property registration in Japan, land and building are considered two separate objects so that the registration process is carried out separately [3]. Therefore, their legal status is also separated which enables them to also be used as individual collaterals. The Immovables Registration Law, Law Number 24 February 1899 and Law Relating to Standing Timbers, Law Number 221909 states that "the most significant practical result of this distinction between land and structures thereon is that building may be owned separately disposed of. In addition, the land and buildings may separately be used as collateral securing obligations of the owner" [4]. 
The application of the principle of horizontal separation in Japan differs from that in Indonesia as land and building have separate registration processes and certificates as proof of rights in Japan, enabling them to become separate legal objects (e.g., collaterals) [5].

In Indonesia, although land and buildings are also legally recognized as two separate objects, only certain rights to land and apartment units are issued certificates as proof of rights in practice [6]. Currently, many buildings do not have separate certificates even though the principle of horizontal separation demands this.

This causes legal problems for building owners, especially those owning property on land owned by others, in offering their property as collateral [7]. They will always have to depend on the decision of the landowner as the holder of the proof of ownership, as banks will only accept a building as collateral if there is written approval from the owner of the land rights in which the building is erected. These landowners are not obligated in any shape or form to provide their approval.

Another problem can be found in the execution of collaterals. Currently, there are no clear procedures in the transfer of building rights from the guarantor to the buyer [8].

These problems have caused banks to be hesitant in receiving buildings without land rights as collateral, even those with high prices and are backed by a normative legal basis.

The main problem in this paper is formulated as follows: Is it possible for the Government of Indonesia to create a certification agency for buildings without land rights? To answer this problem, this paper utilizes a comparative law approach on laws related to the property system in Japan and Indonesia.

\section{Research Method}

This paper utilizes a comparative law approach on laws related to the property system in Japan and Indonesia. Secondary data as legal material is obtained through the Building Law, the Mortgage Law, the Fiduciary Security Law, and national and international journals that are used as reference material. Conclusions are drawn with qualitative analysis.

\section{Results and Discussion}

Prior to the enactment of the Basic Agrarian Law on September 24, 1960, land law dualism was in force, which consisted of the 'western land law' derived from the Civil Code and 'customary land law' derived from customary law [9]. The 'western land law' applied natrekking/accesie (the principle of accession) as outlined in Article 500, Article 572, and Article 601 of the Civil Code while the customary land law applied horizontale scheiding (the principle of horizontal separation).

\subsection{Difference between the Horizontal Separation Principle and the Vertical Accession Principle}

The vertical accession and horizontal separation principles address the relationship between land and the objects erected on it differently. In this case, the principle of accession explains that land ownership covers buildings, plants, and objects erected on it. In other words, the landowner is automatically considered the owner of any buildings on it. Meanwhile, the 
principle of horizontal separation separates the ownership of land and any objects on it. Therefore, the party responsible for the construction of a building is considered its owner, regardless of land ownership.

The Basic Agrarian Law replaces land law dualism with a national land law system that is registered in the national spirit (volksgeist) of Indonesia. In other words, the articles contained in the Basic Agrarian Law are the realization of customary law as the "main basis" and "supplement" [10]. This is contained in the preamble of the letter a, Article 2 Paragraph (4), Article 3, and the explanation of Article 5 of the Basic Agrarian Law. On this basis, Indonesia applies and is subject to the principle of horizontal separation.

The differences in the vertical accession and horizontal separation principles can be seen in the table below:

Table 1. Differences in the Vertical Accession and Horizontal Separation Principles

\begin{tabular}{lll}
\hline \multicolumn{1}{c}{ Difference } & Horizontal Separation Principle & Vertical Accession Principle \\
\hline Source & Indonesian Customary Law & Western Laws \\
\hline Legal Basis & $\begin{array}{l}\text { the preamble of the letter a, Article 2 } \\
\text { Paragraph (4), Article 3, and the } \\
\text { explanation of Article 5 of the Basic } \\
\text { Agrarian Law. }\end{array}$ & $\begin{array}{l}\text { Article 500, Article 572, and } \\
\text { Article 601 of the Civil Code. }\end{array}$ \\
\hline Rights Owner & $\begin{array}{l}\text { Primary and secondary rights holders } \\
\text { (two parties) }\end{array}$ & $\begin{array}{l}\text { Land rights holders are also } \\
\text { building rights holders (one } \\
\text { party) }\end{array}$ \\
\hline Proof of Rights & Building Ownership Certificate & Land Rights Certificate \\
\hline $\begin{array}{l}\text { Overseeing } \\
\text { Institution } \\
\text { Execution } \\
\text { Certainty) }\end{array}$ & $\begin{array}{l}\text { Mortgage rights } \\
\text { Fiduciary } \\
\text { Difficult; primary and secondary } \\
\text { rights holders may be different } \\
\text { parties }\end{array}$ & $\begin{array}{l}\text { Hypoteek } \\
\text { Mortgage rights } \\
\text { Straightforward; the rights } \\
\text { holder is one party }\end{array}$ \\
\hline $\begin{array}{l}\text { Benefits } \\
\text { (Futuristic) }\end{array}$ & $\begin{array}{l}\text { Supports development as it will not } \\
\text { be limited by land area }\end{array}$ & $\begin{array}{l}\text { Inhibits development as the } \\
\text { population continues to grow, } \\
\text { reducing the area of land that } \\
\text { can be developed }\end{array}$ \\
\hline
\end{tabular}

Source: Processed secondary data, specifically related laws and regulations.

Based on the table, the principle of horizontal separation supports population growth as available land continues to decrease. However, it provides less legal certainty as the building ownership certificate has not been realized.

The principle of vertical accession requires further revisions as it denies building ownership for those not in possession of land rights. This principle does not support rapid population growth and seems to be more catered to capitalists who own large swaths of land.

\subsection{Land and Building Owners as Different Entities}

The national land law gives authority to primary and secondary land rights holders to control and use the land. Primary/original rights are directly granted by the state to the rights holders. It is obtained through an application for rights to the state (e.g., Ownership Rights, Building Rights on Land, Right of Exploitation, Use Rights, and Management Rights). Secondary/derivative rights arise or are imposed on existing land rights. It is obtained through 
an agreement between the primary rights holder with the prospective secondary right holder (e.g., Lease Rights on Land, Building Rights on Land, Right of Exploitation, and Use Rights)

Land ownership can be proven with a land certificate which acts as proof of title; this is considered a strong piece of physical and juridical evidence [11]. Meanwhile, building ownership can be proven with a Building Ownership Certificate issued by the local government [12].

More than one Building Ownership Certificate can be issued for a building; it can be owned by multiple parties. In addition, building ownership can be transferred to other parties.

Parties wishing to construct a building must do so on land with a clear ownership status. Those who do not own land can do so on land owned by other parties by obtaining the approval and land use permit from the land rights holder in the form of a written agreement.

The written agreement must be made before the relevant authorities and contain at least: the rights and obligations of the parties, area, location, land boundaries, building function, and duration of land use.

\subsection{Emulating the Japanese Property System}

As there have been no government regulations issued regarding building certificates based on the Building Law to date, the Japanese property system, which adheres to the principle of horizontal separation can be referred to [3].

Japanese land law has seen innovations since the modernization of 'chiso-kaisei' (land tax law). Since the feudal Tokugawa Government in 1868 (Meiji Era) was overthrown, the Meiji Era Government rejected and attempted to modernize the feudal land system. The modernization of land ownership and the land tax system was of great importance to the government as 'chiso' (land tax) was the only source of government revenue at that time [3]. For these reasons, it was necessary: 1) to recognize the freedom to sell real property, which was officially banned by the Tokugawa Government; 2) to establish a modern regime of real property, and; 3) to provide new landowners with certification. This certification was known as 'chiken' (property certificate) [13].

Following preparations made by the Ministry of Finance for the Okubo Government, the freedom to sell land was declared in February 1872. In the same year, 'chiken' was issued to all private land. This certification is non-negotiable as it is intended to be a legal guarantee. Following the issuance of the 'Fudousan-touki-hou' (Land Registration Act) in 1899, 'chiken' was replaced with the Registration system and no longer exists since then. On July 28, 1873, the 'Chiso-kaisei-hou' (Dajoukan Proclamation Number 272 of 1873) was announced and a new land tax was imposed. The annual tax rate was set to $3 \%$ of the land value and eliminates years of 'remissio mercedis' (tax exemption due to poor harvest) that occurred under the Tokugawa system. The tax rate is relatively high as the law aims to maintain a national income stream that is substantially the same as the Tokugawa system [3].

The modern Japanese property regime is a by-product of the modernization of the tax system. There are many irrational points regarding taxation, especially heavy taxation (including infra (2)). In 1877, the tax rate was lowered to $2.5 \%$ after massive riots in several districts against the 1876 New Tax Law [3].

a. In most western countries, land and building are considered a single unit.

Land and building share the same interests. In Japan, however, they are treated as separate entities under property law. As buildings are considered independent immovable property, there is a separate registration system for land and buildings. This practice originates from a Japanese 
tradition during the enforcement of the Japanese Civil Code ${ }^{1}$. The first Japanese Civil Code also followed this tradition [3].

German BGB $\S 94$ (1) states that: "The essential parts of a plot of land include the things firmly attached to the land, in particular buildings, and the produce of the plot of land, as long as it is connected with the land. A seed becomes an essential part of the plot of land when it is sown, and a plant when it is planted"; On the other hand, under German law, buildings and products from land that cannot be separated without one or the other being destroyed or undergoing a change of nature are considered 'wesentliche Bestandteile' (essential parts) and cannot be the subject of separate rights [3].

b. Land and buildings do not necessarily have to be owned by different parties, as a building cannot continue to exist without land. In fact, in most cases in Japan, both are owned by the same party.

However, there are cases where a building belongs to another party. This primarily occurs from the mandatory sale of land or buildings erected on it. The Japanese Civil Code contains provisions regarding 'statutory superficie' ('houtei chijouken'), including Article 388 which states that: "If the land and buildings on it belong to one party and either is mortgaged, then the debtor is deemed to have created a superficie for buyers in an official auction. In such a case, the lease will be determined by the Court based on the claim of the parties concerned"2.

For example, A obtains 'chinshakuken' (the right to lease land) on B's land and builds a house on it, and B then sells the land to C. In this case, A cannot continue leasing as the right only states B as the leaser. This is known as 'Kauf bricht Miete' (lease broken due to sale). C can demand the house to be moved. If A has full ownership of the house and B sells the land to $\mathrm{C}$, then the land will belong to $\mathrm{C}$ and $\mathrm{A}$ can claim compensation for unfair treatment with a value equal to the house [3].

Article 605 of the Japanese Civil Code states that: "A lease of immovable property, when registered, shall also be effective against a person who subsequently acquires real rights for the immovable property". This provision aims to protect A from the sale between B and C. In practice, however, lease registrations are rare. Landowner's dislike and refuse any form of registration related to Article 605. After the enactment of the Civil Code in Japan, the new law was enacted in 1909. Article 1 of 'Tatemono-hogo-hou' of 1909 (Law on Protection of Buildings on Leased Land) states that: "even in non-registered land if the land tenant owns a registered building, the rights are effective towards whoever obtains real ownership rights to the land. In this case, land tenants do not need to register the leased land, only the building itself". 'Tatemono-hogo-hou' allows A to lease the land from the new landlord, C, by registering the house. A cannot register a lease on the land register without the consent of the landowner but can register his ownership on the housing register on their own accord. The following laws allow A to enforce their right under lease towards the new homeowner through a handover of the building [3].

Article 1 Paragraph (1) of the Rented Housing Act states that: "Although not registered, building lease must be carried out if it has been handed over, and is effective towards anyone who obtains real rights to the building. In this case, the tenant does not need to have registered the building being rented out; only a handover is required" [14].

\footnotetext{
${ }^{1}$ Since traditional Japanese buildings are small and made of wood, it is relatively easy to move them into sections. Sometimes buildings are treated as movable rather than immovable property.

${ }^{2}$ Many problems arise from a system that treats land and any buildings on it as an independent interest. Cf. Ono,

Hougaku-Kenkyu No. 36, p. 69, note 12.
} 
The statements in this section establish that Japan has a legal institution that issues certificates for buildings without land rights. Japan implements a registration system in handling rights to buildings without land rights.

Registry offices are divided between those that conduct registration affairs using a computer system by preparing a registry on a magnetic disk (computer-based offices) and those that conduct registration affairs by keeping a registry in binder format in which land/building registration forms are organized in files (book-based offices).

a. Computer-based offices: a registry is prepared on a magnetic disk. At computer-based offices, anyone can be issued a certificate of registered matters (document certifying the whole or part of the registered matters) and anyone can be issued a written outline of registered matters (document stating the outline of registered matters) by submitting a prescribed request form. This certificate of registered matters is the same content as a transcript or extract of a registry.

b. Book-based offices: a registry, which organizes registration forms in files, consist of a land registry and a building registry. At book- based offices, anyone can be issued a transcript or extract of a registry and anyone can inspect a registry by submitting a prescribed request form.

\subsection{Formulating a Certification Agency for Buildings without Land Rights Based on the Principle of Horizontal Separation in Indonesia}

The principle of horizontal separation as reflected in the Basic Agrarian Law has been further developed with the promulgation of the Building Law. However, there are currently no related government regulations that act as implementing regulations. This has caused the Building Ownership Certificate to be unable to be issued. Even though in a 'legalistic positivist' manner (legal point of view), fiduciary security institutions will accept collateral of assets bound to the principle of horizontal separation, banking institutions as creditors much less prefer to deal with such assets, even if it fetches an excellent price, as they do not have legal certainty.

The findings show that the establishment of a Certification Agency for buildings without land rights based on the Japanese system can solve these legal problems.

The land is regulated in the fourth part of Law Number 11 of 2020 concerning Job Creation (also known as the Omnibus Law). The first paragraph, as contained in Articles 125 to 135, regulates the "land bank". The second paragraph regulates the Reinforcement of Management Rights as contained in Articles 136 to 142. The third paragraph regulates Apartment Units for Foreigners as contained in Articles 143 to 145. The fourth paragraph regulates the Granting of Land/Management Rights to Attics and Basements in Articles 146 and 147.

Article 125 of the Omnibus Law states that the central government is to establish a land bank agency, defined as a "special agency that manages land". Article 126 Paragraph (1) of the Omnibus Law states that the land bank agency guarantees the availability of land for public and social interests, national development, economic equality, land consolidation, and agrarian reform to ensure a just economy. The land bank agency utilizes restricted state assets and functions to carry out planning, acquisition, procurement, management, utilization, and distribution of land. Therefore, the agency is responsible for issuing rights to buildings without land rights. Banks are obliged to accept such buildings as collateral as it has legal certainty.

The government can use the Japanese Building Registration Agency as a basis in forming the Land Bank Agency. Laws or implementing regulations are to be issued from the Building 
Law that has been promulgated previously.

The regulations regarding rights to buildings without land rights that can be transplanted from Japan are as follows: First, land and any buildings erected on it are treated as separate entities in property law. As buildings are considered independent immovable property, there is a separate registration system for land and buildings. This practice originates from a Japanese tradition during the enforcement of the Japanese Civil Code. Second, a land tenant erecting a building on land can renew their lease to a new landowner by registering the building; they are not obliged to register the land. Third, the owner of a building without land rights cannot register the lease on the land register without the consent of the landowner. However, they can register the ownership of the building on the register of buildings without land rights with no additional requirements.

Japan has established a legal institution for issuing building certification that is independent of land rights. This system can be transplanted and implemented in Indonesia.

\section{Conclusion}

The principle of horizontal separation, which is manifested in the form of the right to construct a building on land owned by other parties, greatly supports economic activity. Through this principle, legislators can secure future developments of the country through the Building Law and Omnibus Laws as land availability continues to decrease while the need for land increases. To ensure legal certainty, the Indonesian government should create a certification agency for buildings without land rights based on the property system in Japan. In doing so, buildings without land rights can be used as collateral due to possessing both economic value and legal certainty.

\section{References}

[1] H. Hasbullah, "Asas Pemisahan Horizontal (Horizontale Scheiding) dalam Hukum Tanah di Indonesia dan Permasalahannya," J. Huk. Pembang., vol. 22, no. 1, pp. 77-87, 1992.

[2] B. Rubiati, Y. Pujiwati, and M. Djakaria, "Kepastian Hukum Kepemilikan Rumah Susun Bagi Masyarakat Berpenghasilan Rendah," Bina Huk. Lingkung., vol. 1, no. 2, pp. 134-145, 2017.

[3] S. Ono, "A Comparative Study of the Transfer of Property Rights in Japanese Civil Law (1)," Hitotsubashi J. law Polit., no. 31, pp. 1-22, 2003.

[4] E. Ramelan, "Asas Pemisahan Horizontal dalam Hukum Tanah Nasional (Bagian IV)," Gagasan Hukum, 2009. [Online]. Available: https://gagasanhukum.wordpress.com/2009/01/12/asaspemisahan-horizontal-dalam-hukum-tanah-nasional-bagian-iv/. [Accessed: 28-Nov-2020].

[5] D. D. M. Ganindra and F. Kurniawan, "Kriteria Asas Pemisahan Horizontal Terhadap Penguasaan Tanah dan Bangunan," Yuridika, vol. 32, no. 2, pp. 228-259, 2017.

[6] Pemerintah Republik Indonesia, Article 9 Paragraph (1), Articles 29 and 30 of the Replublic of Indonesia Regulation Number 24 of 1997 concerning Land Registration. 1997.

[7] R. Usman, "Hukum kebendaan," Jakarta Sinar Graf., 2011.

[8] M. Isnaeni, "Hukum Benda dalam Burgerlijk Wetboek," PT Revka Petra Media, Surabaya, 2016.

[9] H. M. Yamin, Beberapa Masalah Aktual Hukum Agraria. Pustaka Bangsa Press, 2004.

[10] Considerant Letter a, Article 2 Paragraph (4), and Explanation of Article 5 of the Basic Agrarian Law.

[11] Pemerintah Republik Indonesia, Article 32 of the Republic of Indonesia Regulation Number 24 of 1997 concerning Land Registration. 1997.

[12] Pemerintah Republik Indonesia, Article 8 Paragraph (1) Law Number 28 of 2002 concerning Buildings; Article 1 point (19) and point (21) of the Republic of Indonesia Regulation Number 16 
of 2021 concerning Regulation Implementation of Buildings Law. .

[13] Tokugawa Government, Fuduosan-touki-hou 1994 (Japanese Land Registration Law). 1994, p. 6.

[14] Yoshimi, “Tentang Perlindungan Penyewa di Jepang,” Hitotsubashi J. Law Polit., vol. 1, p. 54, 1960. 